\title{
KOGNISI SOSIAL DALAM PROSES ANALISIS WACANA KRITIS MODEL VAN DIJK PADA BUKU MOTIVASI
}

\section{SOCIAL COGNITION IN THE PROCESS OF ANALYSIS OF CRITICAL DISCUSSION MODEL VAN DIJK IN A MOTIVATION BOOK}

\author{
Febrina Yusar $^{1 *}$, Sukarelawati $^{2}$, Agustini $^{3}$. \\ ${ }^{123}$ Program Studi Sains Komunikasi, Fakultas Ilmu Sosial dan Ilmu Politik, Universitas Djuanda Bogor \\ Jl. Tol Ciawi No. 1 kotak Pos 35, Bogor 16740
}

*Korespondensi: Febrina Yusar, fbrnysr@gmail.com

(Diterima oleh Dewan Redaksi: 15 Juni 2020)

(Dipublikasikan oleh Dewan Redaksi: 5 Oktober 2020)

\begin{abstract}
The large number of critical discourses in the book "The Subtle Art of Not Giving a Fuck" has made many readers curious and has made it the best-selling motivational book in Indonesia. It makes readers curious about what influenced Manson in the process of that critical discourse. Related to this, the study aims to determine the critical discourse analysis of social cognition from the Van Dijk model. The research method used is Van Dijk's model of critical discourse analysis. The data collection technique is to observe text or document research, text in the form of primary data as the main target in the analysis, while secondary data is needed to sharpen primary data analysis as well as data used as complementary or comparison material (Mitri, 2010). In this case, primary and secondary data collection is obtained by observing and analyzing documents from the book "The Subtle Art of Not Giving a Fuck" and Manson's personal blog. The results showed that there are several factors that influenced Manson's social cognition, one of which was culture or belief. Manson described it explicitly (express) through the text of discourse. The conclusion of the research results is that there are two factors that influence social cognition in critical discourse. Tthere are knowledge, opinions and attitudes. Knowledge can be seen from the culture and social life experienced by the writer, a culture that is too obsessed with good things, while the author expresses opinions and attitudes towards the social life he experiences and that also affects the process of making discourse.
\end{abstract}

Keywords: critical discourse; Van Dijk's model; social cognition; motivational book 


\begin{abstract}
ABSTRAK
Banyaknya wacana kritis dalam buku Sebuah Seni Untuk Bersikap Bodo Amat membuat banyak pembaca penasaran dan menjadikannya buku motivasi best seller toko buku di Indonesia. Penggunaan wacana kritis yang dibuat Manson membuat pembaca penasaran apa yang mempengaruhi Manson dalam proses wacana kritis tersebut. Terkait hal itu penelitian bertujuan untuk mengetahui analisis wacana kritis kognisi sosial dari perangkat model Van Dijk. Metode penelitian menggunakan analisis wacana kritis model Van Dijk. Teknik pengumpulan data melakukan observasi teks atau document research yaitu teks berupa data primer sebagai sasaran utama dalam analisis sedangkan data sekunder diperlukan guna mempertajam analisis data primer sekaligus data dijadikan bahan pelengkap atau perbandingan (Mitri, 2010). Dalam hal ini pengumpulan data primer dan sekunder diperoleh dengan observasi mengamati dan menganalisis dokumen dari buku "Sebuah Seni Untuk Bersikap Bodo Amat" serta blog pribadi Manson. Hasil penelitian menunjukan bahwa ada beberapa faktor yang memengaruhi kognisi sosial Manson salah satunya adalah faktor budaya atau kepercayaan. Manson menjabarkannya secara eksplisit (tersurat) melalui teks wacana. Kesimpulan hasil penelitian ada dua faktor yang mempengaruhi kognisi sosial pada wacana kritis yaitu pengetahuan, opini dan sikap. Pengetahuan dapat dilihat dari budaya dan kehidupan sosial yang dialami oleh penulisnya Manson yaitu budaya yang terlalu terobsesi dengan hal-hal baik. Sedangkan penulis mengemukakan opini serta sikap terhadap kehidupan sosial yang dialaminya dan hal itu juga yang memengaruhi proses pembuatan wacana. Kata Kunci: wacana kritis; model Van Dijk; kognisi Sosial; buku motivasi
\end{abstract}

Febrina Yusar, Sukarelawati, Agustini. 2020. Kognisi Sosial Dalam Proses Analisis Wacana Model Van Dijk pada Buku Motivasi. Jurnal Komunikatio: 6 (2): 65-76.

\title{
PENDAHULUAN
}

Sejak buku Sebuah Seni Untuk Bersikap Bodo Amat terbit secara resmi di Indonesia banyak masyarakat Indonesia yang tertarik untuk membaca salah satu buku motivasi ini. Buku ini dikategorikan sebagai buku motivasi disebut buku anti gerakan motivasi. Hal ini dikarenakan banyaknya penggunaan wacana kritis dalam buku. Manson adalah seorang penulis buku Sebuah Seni Untuk Bersikap Bodo Amat, awalnya penulis blog atau biasa disebut blogger yang menulis keresahannya tentang kehidupan sosial disekitarnya dalam blog pribadinya. Banyaknya pembaca yang menyukai tulisannya akhirnya Manson memutuskan untuk membuat buku motivasi yang berjudul The Subtle Art of Not Giving A $F^{*} c k$ yang sekarang sudah diterjemahkan ke dalam bahasa Indonesia yaitu Sebuah Seni Untuk Bersikap Bodo Amat. Dalam bukunya Manson banyak mengkritisi orang-orang yang terlalu memperdulikan banyak hal tidak berguna. Manson juga mengkritik para motivator yang selalu memberi motivasi tentang bagaimana menjadi orang yang baik. Manson mempunyai pandangan yang berbeda bahwa kita sebagai manusia tidak perlu berusaha untuk menjadi orang baik. Kunci dari kebahagian adalah menerima diri sendiri seperti yang tertulis pada bab satu.

Terkenal dengan wacana kritisnya membuat pembaca penasaran dengan kognisi sosialnya atau hal apa yang mempengaruhi Manson sehingga membuat buku motivasi yang justru mempunyai pandangan berbeda dengan buku motivasi 
lainnya. Pendekatan yang digunakan dalam penelitian adalah analisis wacana kritis model Van Dijk. Analisis wacana

kritis model Van Dijk merupakan suatu pendekatan analisis wacana yang sering digunakan karena dianggap praktis dalam penerapannya. Analisis wacana kritis model Van Dijk sering disebut sebagai analisis wacana kognisi sosial karena Van Dijk tidak hanya melihat dari struktur teks nya saja melainkan Van Dijk juga melihat bagaimana suatu wacana bisa terbentuk. Van Dijk melihat wacana dari tiga aspek yaitu struktur teks, kognisi sosial, dan konteks sosial. Analisis struktur teks meliputi analisis struktur makro, supertruktur, dan struktur mikro. Lalu kognisi sosial sendiri meliputi pengetahuan (knowledge) serta opini dan sikap. Aspek terakhir konteks sosial yaitu meliputi konteks kultural dan situasi.

Analisis wacana model Van Dijk mengacu pada penggabungan ketiga dimensi wacana tersebut ke dalam satu kesatuan analisis. Pada bangunan teks yang diteliti bagaimana struktur teks dan strategi wacana yang digunakan untuk menegaskan suatu topik tertentu. Pada tahap kognisi sosial dibahas proses produksi teks informasi yang melibatkan kognisi individu dari penulis. Sedangkan tahap ketiga mengkaji bangunan wacana yang berkembang dalam masyarakat akan suatu masalah yang mempengaruhi kognisi penulis (Musyafa'ah, 2017). Pendekatan ini memiliki pandangan bahwa kognisi sosial merupakan elemen penting dalam proses pembentukan sebuah wacana di masyarakat. Sebuah wacana memiliki kecendrungan tertentu karena kognisi atau kesadaran mental yang ada dalam diri penulis, bahkan kesadaran masyarakat tempat dimana wacana itu muncul (Dijk dalam Eriyanto, 2002).

Pembentukan suatu wacana dengan melibatkan kesadaran masyarakat dan penulis tentu saja di dalam nya terjadi komunikasi sehingga penulis dapat menerima pesan atau informasi dari fenomena atau budaya masyarakat sosial setempat sehingga memengaruhi pemikiran penulis. Analisis wacana kritis model Van Dijk tidak dibatasi hanya pada struktur teks karena wacana itu sendiri menunjukkan dan menandakan sejumlah makna, pendapat, dan ideologi. Untuk mengetahui bagaimana makna tersembunyi dalam teks dibutuhkan suatu analisis kognisi sosial. Penelitian kali ini peneliti akan memfokuskan pada aspek analisis wacana kritis kognisi sosial dalam buku "Sebuah Seni Untuk Bersikap Bodo Amat" yang dimana buku tersebut adalah buku motivasi karya Mark Manson yang terkenal dengan wacana kritisnya. Maka berdasarkan uraian diatas dapat diambil rumusan masalah yaitu: "bagaimana analisis wacana kritis kognisi sosial model Van Dijk pada tokoh dalam buku "Sebuah Seni Untuk Bersikap Bodo Amat"?

\section{MATERI DAN METODE PENELITIAN}

\section{MATERI}

\section{Analisis Wacana Kritis}

Gee dalam (Hamad, 2005) analisis wacana adalah penggunaan bahasa untuk menggambarkan realitas. Menurut definisi kerja ini wacana dibedakan menjadi dua jenis yaitu: 
1. discourse (d kecil) yaitu penggunaan bahasa pada tempatnya. Biasanya discourse

ini banyak menjadi perhatian para ahli bahasa.

2. Discourse (D besar) yaitu penggunaan bahasa pada tempatnya yang dihubungkan dengan unsur-unsur nonbahasa yang berupa kepentingan politik, ideologi, kehidupan sosial, dll.

Althusser dalam (Eriyanto, 2012) menjelaskan wacana sebagai praktik dimana seseorang diposisikan dalam posisi tertentu dalam hubungan sosial. Wacana berperan dalam mendefinisikan individu dan memposisikan sesorang dalam posisi tertentu. Wacana tertentu membentuk subjek dalam posisi-posisi tertentu dalam rangkaian hubungan dengan kekuatan sosial yang ada dalam masyarakat. Seperti dalam penelitian ini wacana-wacana dalam buku memposisikan para tokoh sebagai pihak yang negatif dan penulis sebagai pihak yang positif.

Mengutip apa yang dipaparkan dalam buku analisis wacana (Eriyanto, 2002), berikut ini merupakan hal-hal yang mencirikan sebuah analisis wacana kritis yaitu:

1. Tindakan, wacana dipahami sebagai sebuah tindakan. Dipahami juga sebagai bentuk interaksi dan komunikasi. Jadi, wacana merupakan sesuatu yang digunakan untuk memengaruhi, mendebat, membujuk, menyanggah, dan sebagainya. Wacana juga merupakan sesuatu yang diekspresikan secara sadar dan terkontrol.

2. Konteks, dalam konteks wacana juga memeriksa konteks dari komunikasi seperti siapa yang

mengkomunikasikan atau

komunikator dan dengan siapa berkomunikasi, mengapa, dan dalam situasi seperti apa serta menggunakan media apa dalam berkomunikasi.

3. Historis, untuk memahami suatu teks wacana maka dapat dilakukan dengan konteks historis. Pada saat menganalisis perlu diketahui dimana wacana tersebut berkembang dan seperti apa dikembangkannya. Mengapa wacana tersebut bisa terbentuk dan bagaimana proses terbentuknya wacana.

4. Kekuasaan, dalam hal kekuasaan melihat bagaimana wacana tersebut dapat mengontrol masyarakat. Dalam penelitian ini tidak didapatkannya wacana kekuasaan.

5. Ideologi, wacana yang digunakan sebagai alat oleh kelompok dominan untuk mempersuasi dan mengkomunikasikan kekuasaan yang dimiliki agar terlihat absah dan benar dimata khalayak.

\section{Kerangka Berpikir}

\section{Model Analisis Wacana Van Dijk}

Analisis wacana model Van Dijk mengacu pada penggabungan ketiga dimensi wacana yaitu analisis struktur teks, analisis kognisi sosial, dan analisis konteks sosial ke dalam satu kesatuan analisis. Pada bangunan teks yang diteliti adalah bagaimana struktur teks dan strategi wacana yang digunakan untuk menegaskan topik tertentu. Tahap kognisi sosial yang dibahas adalah proses produksi pada teks, yang melibatkan individu dari penulis itu sendiri. Dalam penelitian ini tentunya melibatkan Mark Manson selaku 
penulis buku. Sedangkan tahap ketiga yaitu konteks sosial membahas tentang bangunan wacana yang berkembang dimasyarakat akan suatu masalah yang mempengaruhi kognisi penulis (Musyafa'ah, 2017).

Fokus penelitian pada analisis kognisi sosial dalam wacana buku "Sebuah Seni Untuk Bersikap Bodo Amat" dalam proses analisis ada beberapa aspek yang perlu diperhatikan. Menurut (Eriyanto, 2002), perlu adanya penelitian mengenai kognisi sosial yaitu kesadaran mental penulis yang membuat teks tersebut. Dalam pandangan Van Dijk, analisis tidak hanya dibatasi dari analisis struktur teks saja melainkan juga proses produksi dari praktik wacana tersebut yang didalamnya terdapat tindakan, ideologi, kekuasaan dan lain-lain yang turut ikut campur dalam pengelolaan teks yang kompleks.

Kognisi sosial merupakan tahap kedua dari proses pembentukan teks. Tahap ini dikenal dengan jembatan penghubung antara fenomena atau peristiwa dengan teks wacana dimana tulisan dipengaruhi oleh kesadaran mental penulis dan kesadaran mental pembaca wacana. Dalam tahap inilah komunikasi berlangsung dengan adanya pesan yang diterima Manson sehingga mempengaruhi proses pembentukan teks wacana.

Adapun model analisis Van Dijk dapat digambarkan sebagai berikut:

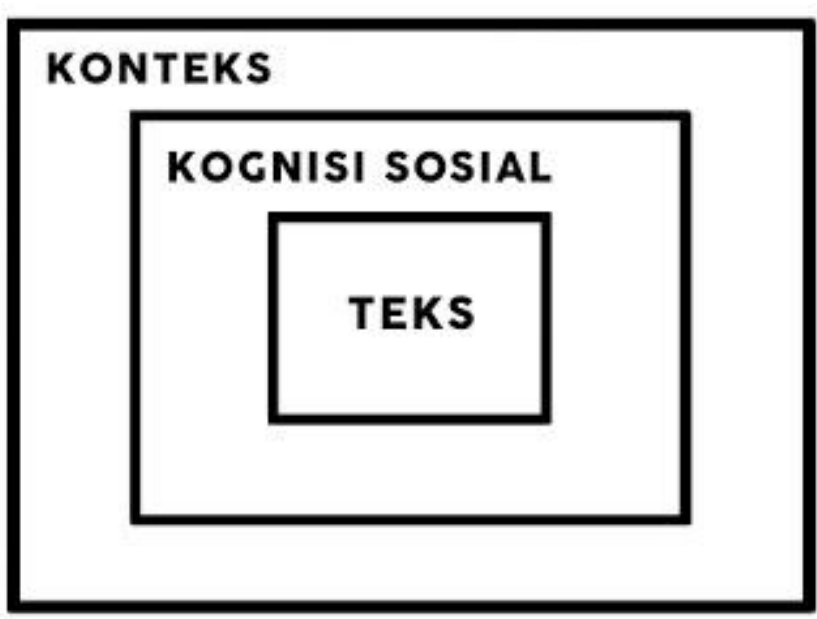

\section{Gambar 1. Model Analisis Van Dijk}

Terkait dengan model analisis Van Dijk kerangka berpikir kognisi sosial dalam proses analisis wacana kritis pada buku motivasi yaitu wacana dibuat dengan kesadaran, pengetahuan tentang fenomena sosial dan prasangka. Sebuah fenomena sosial tentang pelaku, kronologi dan informasi-informasi kecil dipandang dari sudut pandang yang berbeda oleh penulis dan pembaca wacana. Penulis memiliki pandangan tersendiri terhadap fenomena sosial tersebut dan akan menghasilkan wacana kritis (Eriyanto, 2002). Berdasarkan penjelasan kognisi sosial di atas kita dapat menyimpulkan ada beberapa elemen yang harus diperhatikan terkait dengan kognisi sosial yaitu:

\section{Pengetahuan}

Pengetahuan (Knowledge) membahas tentang kepercayaan faktual yang dibagikan kelompok atau budaya. Penulis menyatakan wacananya berdasarkan pengetahuan yang diperoleh dari pengalaman pribadi atau kelompoknya (Humaidi, 2017). Model analisis wacana Van Dijk menggunakan tiga metode untuk menganalisis perwujudan pengetahuan 
dalam wacana yaitu ekspresi eksplisit pengetahuan (the explicit expression of knowledge) yaitu mengacu pada proposisi yang secara eksplisit yang mengacu pada pengetahuan penulis yang disampaikan secara eksplisit. Sedangkan pengetahuan implisit (implicit knowledge) yaitu proposisi yang mengisyaratkan peristiwa atau pengetahuan khusus dan yang terakhir adalah pengetahuan kontekstual (contextual knowledge) yaitu mengamati proposisi yang menunjukkan peristiwa yang umumnya sudah diketahui oleh pembaca.

\section{Opini dan Sikap}

Menurut (Humaidi, 2017) pada elemen opini dan sikap membahas tentang pendapat atau kepercayaan evaluatif penulis terhadap sesuatu. Penulis buku ini akan mengemukakan pendapat serta sikap terhadap suatu peristiwa melalui wacana teks. Opini dan sikap dapat terlihat melalui analisis skemantik atau alur jalannya cerita. Biasanya penulis akan menunjukkan pendapat atau kepercayaan dan juga sikapnya pada babak resolusi yaitu babak terakhir dalam skemantik. Wacana tersebut bisa ditunjukkan secara langsung atau tidak langsung seperti membuat cerita pada tokoh untuk mewakilkan opini serta sikap penulis. Penulisnya menunjukkan opini dan sikap secara langsung tidak melalui para tokoh dalam cerita.

\section{Tokoh}

Tokoh merupakan individu yang memiliki peran dalam cerita. Menurut Sudjiman dalam (Siswasih, 2007) tokoh adalah individu yang mengalami peristiwa atau berkelakuan di dalam berbagai peristiwa dalam cerita. Dalam Kamus Besar Bahasa Indonesia (Lektur. ID) dituliskan tokoh adalah pemegang peran atau tokoh utama (roman atau drama).

Maka individu atau tokoh dianggap hal yang paling utama dalam suatu cerita. Hal ini dikarenakan tokoh dapat membuat pembaca lebih mendalami isi cerita melalui karakter-karakter tokoh yang ada.

\section{METODE PENELITIAN}

Metode penelitian yang digunakan adalah analisis wacana model Van Dijk. Menurut Littlejohn dalam (Eriyanto, 2002) antara bagian teks dalam model van Dijk dilihat saling mendukung, mengandung arti yang koheren satu sama lain. Hal ini karena semua teks dipandang Van Dijk mempunyai suatu aturan yang dapat dilihat sebagai suatu piramida. Bahasa dalam wacana kritis dipandang sebagai representasi yang membentuk subjek, tema, maupun ideologi tertentu. Analisis wacana kritis memandang bahasa sebagai faktor yang penting, bahasa tersebut digunakan dalam melihat ketimpangan kekuasaan yang terjadi di masyarakat.

Teknik pengumpulan data primer sendiri didapat dari buku "Sebuah Seni Untuk Bersikap Bodo Amat" dan buku-buku serta blog pribadi Manson sebagai data sekunder. Penelitian ini lebih memfokuskan pada analisis kognisi sosial model Van Dijk karena kognisi sosial adalah perangkat yang paling utama dalam analisis wacana kritis model Van Dijk. 


\section{HASIL DAN PEMBAHASAN}

\section{HASIL}

Pada level kognisi sosial ini, data didapatkan dari beberapa unggahan blog pribadi Manson yaitu markmanson.net, situs resmi penerbit buku Grasindo dan dari buku "Sebuah Seni Untuk Bersikap Bodo Amat" itu sendiri. Buku ini ditulis berdasarkan keresahan pribadi seorang Mark Manson terhadap pendapatpendapat umum para motivator. Buku ini pun disebut seperti buku gerakan antimotivasi karena isinya yang dinilai bertolak belakang dengan teori-teori motivasi meski hakikatnya informasi yang disampaikan dalam buku ini pun berupa motivasi dengan gaya yang berbeda. Wacana dalam buku banyak yang bermaksud untuk mengkritisi kehidupan sosial seperti pada beberapa wacana yang akan peneliti analisis.

Manson menawarkan sebuah seni dengan pendekatan yang waras dengan cara mendorong pembaca untuk menjadi diri sendiri, menerima diri sendiri, dan hanya memperdulikan hal yang penting dan mendesak. Manson beranggapan fenomena sosial yang perlu diluruskan. Biasanya para motivator akan mendorong dan memberi cara untuk menjadi orang yang lebih baik, untuk menjadi orang yang ideal. Namun dalam buku ini Manson justru berkata sebaliknya. Seperti yang tertulis dalam buku : kunci untuk kehidupan yang lebih baik bukan tentang memedulikan lebih banyak hal: tapi memedulikan hal yang sederhana saja. Hanya peduli tentang apa yang benar dan mendesak dan penting.

Wacana di atas adalah salah satu narasi dari tulisan Manson yang bermaksud mengkritisi orang-orang yang terlalu memedulikan sesuatu hal yang tidak seharusnya dipedulikan. Wacana teks di atas merupakan kutipan utama dari buku yang berisi opini pribadi dari Manson. Analisis teks kognisi sosial pada buku "Sebuah Seni Untuk Bersikap Bodo Amat" berdasarkan dua elemen. Pertama adalah pengetahuan, lalu yang kedua adalah opini dan sikap.

\section{Pengetahuan}

Pada elemen pengetahuan membahas tentang kepercayaan faktual yang dibagikan oleh penulis. Kepercayaan faktual tersebut bisa berdasarkan kepercayaan kelompok atau budaya. Penulis menampilkan sejumlah pengetahuan pribadinya, kelompoknya, dan masyarakat secara umum. Informasiinformasi ini ditampilkan untuk memperkuat argumen penulis dalam menilai suatu persoalan. Teks wacana yang dapat diamati melalui elemen ini sebagai berikut: 
Budaya kita hari ini terobsesi untuk mewujudkan harapan-harapan positif yang mustahil diwujudkan: menjadi lebih bahagia, menjadi lebih sehat.

Wacana di atas termasuk ke dalam wacana kritis kognisi sosial yang menampilkan pengetahuan kelompok atau penulis mengenai budaya atau dalam konteks di atas adalah society yang terjadi saat ini terlihat pada kata yang digaris bawahi. Budaya masyarakat yang selalu menganggap bahwa menjadi baik, kaya raya, pendidikan bagus, karir bagus, sehat, cantik, tampan, berperilaku bagus adalah impian setiap orang. Semua orang berlomba-lomba menjadi lebih baik tanpa mengukur diri sendiri.

Beberapa proposisi sebelumnya dipaparkan dalam cerita tokoh Charles Bukowski. Bukowski yang bercita-cita sebagai penulis harus menelan kenyataan karena karyanya selalu ditolak oleh media-media yang pernah ia hubungi karena tulisannya dianggap aneh, menjijikan, dan tidak bermoral. Hal itu menujukkan budaya masyarakat yang menganggap hal-hal negatif adalah suatu kesalahan yang tidak dapat diterima. Selain itu teks wacana lain pada bab empat dengan judul "Problem Bintang Rock" yang menunjukkan pemikiran dari kelompok atau budaya adalah:
Meskipun telah memanfaatkan suatu peristiwa buruk menjadi sesuatu yang positif, seperti yang dilakukan Mustaine dengan Megadeth, pilihannya menggunakan kesuksesan Metallica sebagai alat pengukur hidupnya justru terus menyakiti dirinya puluhan tahun berikutnya.

Teks di atas menampilkan pengetahuan kelompok penulis, teks yang digaris bawahi menunjukan bahwa informasi yang disampaikan adalah informasi faktual yang sudah diketahui oleh masyarakat umum. Dapat kita maknai bahwa meski berhasil bangkit dari keterpurukan jika kita masih menggunakan orang lain sebagai tolak ukur maka hidup kita tidak akan bahagia. Biasanya saat kita mengikuti kelas-kelas motivator kita dimotivasi dan didorong untuk bisa bangkit dari keterpurukan. Setiap manusia pasti pernah mengalami kegagalan dan orang hebat adalah orang yang bisa bangkit dari kegagalannya.

Pada teks wacana sebelumnya dijelaskan bahwa bangkit dari kegagalan serta memanfaatkan peristiwa buruk untuk menjadi hal yang positif tidak selalu dapat membawa kebahagiaan. Pada teks wacana sebelumnya Manson sudah menceritakan peristiwa kegagalan dari Mustaine seorang gitaris dari band legendaris Megadeth. Mustaine memiliki traumanya dengan band Metallica karena dia dikeluarkan dari band tersebut tanpa alasan hingga membuatnya mengalami depresi berat. Meski Mustaine telah berhasil memanfaatkan peristiwa buruk tersebut untuk bangkit dan menjadikannya sukses bersama Megadeth yaitu band kompetitor dari 
Metallica hal itu tetap tidak bisa membuat Mustaine bahagia karena nyatanya Metallica berada diatas Mustaine dalam beberapa penjualan album. Selama ia berkarir ia selalu berpatok pada kesuksesan Metallica dan justru hal itulah yang semakin menyakitinya.

Selanjutnya teks wacana pada bab lima dengan judul "Pilihan" yang menunjukkan pemikiran dari suatu kelompok atau budaya adalah:

Kesadaran itu adalah bahwasanya, kita secara pribadi bertanggung jawab atas segala hal dalam hidup kita, tak peduli seperti apa kondisi diluar hidup kita.

Teks yang digaris bawahi menunjukan penjelasan tentang pengetahuan terlihat pada kata "adalah" dan "bahwasanya" Seperti pada teks wacana di atas yang menjelaskan tentang kesadaran adalah tanggung jawab kita terhadap diri sendiri. Pada teks wacana sebelumnya Manson menampilkan cerita seorang William James yang hidupnya bergantung kepada keluarga. James yang memiliki gangguan kesehatan dengan orang tua kaya raya dan berpengaruh. James bukan anak pintar yang memiliki keistimewaan.

Singkat cerita James kuliah di Universitas Harvard fakultas kedokteran dengan bantuan kekuasaan ayahnya. Namun, hal itu tidak berjalan dengan lancar, dia merasa bahwa pilihan itu tidak cocok dengannya sehingga dia memutuskan untuk keluar hingga membuat ayahnya kecewa. Tidak ada yang berhasil dalam hidupnya. Hidupnya selalu diisi dengan kegagalan dan kekecewaan. Hingga dia memutuskan untuk bereksperimen, ia bertekad akan bertanggung jawab penuh terhadap hidupnya. Hal itulah yang membuatnya menjadi seorang cendikiawan dan bapak filsuf yang berpengaruh pada generasinya.

\section{Opini dan Sikap}

Menurut (Humaidi, 2017), opini dan sikap (opinions and attitudes) membahas tentang kepercayaan evaluatif penulis terhadap sesuatu. penulis akan mengemukakan pendapat dan sikapnya mengenai suatu permasalahan. Penulis menyebarkan kepercayaan ini untuk memengaruhi pembaca agar mengikuti pandangannya. Pengamatan pada elemen ini dilakukan dari segi struktur semantik lokal dan struktur permukaan stilistik. Teks wacana yang termasuk kedalam opini dan sikap adalah:

Dunia secara konstan mencecar anda bahwa jalan menuju kehidupan yang lebih baik adalah lebih, lebih, lebih banyak.

Pada teks di atas dapat dilihat bahwa penulis menggunakan kata "anda" yang menunjukkan bahwa penulis sedang menyampaikan pendapatnya pribadi secara langsung kepada pembaca. Penulis memberikan penilaian terhadap apa yang sedang terjadi. Hal ini ditunjukkan dari teks wacana setelahnya yaitu:

Anda secara konstan dibombardir dengan pesan untuk memmedulikan apa saja, kapan saja. Berpikir untuk membeli TV baru, ornamen baru... Mengapa? Dugaan saya: membeli lebih banyak barang adalah baik. 
Kata "dugaan saya" menunjukkan bahwa teks tersebut merupakan pendapat pribadi penulis. untuk memperkuat argumennya pun penulis sudah menyuguhkan fakta terkait melalui cerita dari tokoh Charles Bukowski. Selain itu, pada bab empat dengan judul "Problem Bintang Rock" yang menunjukkan opini dan sikap adalah:

Sekarang, anda dan saya bisa saja melihat situasi yang dihadapi Dave Mustaine dan tertawa.

Teks di atas menunjukkan bahwa penulis sedang menunjukkan sikap serta kata "saya" pada kalimat di atas memperlihatkan bahwa penulis sedang mengemukakan pendapat pribadi.

Selanjutnya pada bab lima dengan judul "Pilihan" yang menunjukkan opini dan sikap adalah: Entah kita menyadari atau tidak, kita selalu bertanggung jawab atas pengalaman diri kita.

Teks di atas menunjukkan bahwa penulis sedang mengemukakan pendapat pribadinya. Hal itu terlihat pada kata "Entah kita" yang seolah-olah penulis sedang mengajak pembaca untuk berpikir dan meyakinkan pembaca dengan opininya dengan cara mengajak pembaca seolah-olah menjadi tokoh yang sedang diceritakan. Selain itu yang memperkuat bahwa teks wacana tersebut merupakan argumen adalah letak dari teks wacana tersebut ada pada babak resolusi.

\section{PEMBAHASAN}

Buku "Sebuah Seni Untuk Bersikap Bodo Amat" yaitu buku motivasi dengan kategori self improvement karya Mark Manson yang berisi pemikiran-pemikiran Manson mengenai kehidupan sosial masa kini. Sebelumnya Manson sudah terkenal dengan karyanya yang dia tulis di blog pribadinya yang telah berhasil mengoreksi harapan-harapan delusional baik mengenai diri sendiri maupun dunia. Manson mengemukakan pendapat bahwa manusia tidak sempurna dan mempunyai batasan, tidak semua orang harus menjadi baik dan luar biasa. Manson berusaha menyampaikan kepada pembaca bahwa kita harus tahu batasanbatasan diri kita dan menerima apapun yang ada pada diri kita.

Penelitian ini menganalisis buku dengan metode analisis wacana kritis model Van Dijk untuk mengetahui maksud yang terdapat dalam buku melalui wacana-wacana yang digunakan oleh Manson. Peneliti memilih tiga bab sebagai bahan analisis yaitu bab petama dengan judul "Jangan Menyerah" lalu bab empat dengan sub judul "Problem Bintang Rock", lalu yang terakhir adalah bab lima dengan sub judul "Pilihan".

Peneliti memilih bab berdasarkan tokoh yang digunakan Manson sebagai contoh karakter yang akan menggambarkan cerita dalam buku tersebut. Pada wacana kritis model Van Dijk, berusaha memahami maksud dari buku melalui pandangan kognisi sosial dan juga konteks sosial nya tidak hanya dari segi linguistiknya saja. Dalam analisis model Van Dijk kognisi sosial dapat terlihat dari wacana-wacana yang berisi tentang pemikiran budaya serta opini dan sikap.

Berdasarkan buku tersebut penulis banyak memasukan cerita fakta seperti cerita para tokoh yang dianalisis lalu setelahnya penulis memasukkan opini 
pribadinya serta bagaimana penulis menyikapi kejadian dalam cerita tersebut.

\section{Kognisi Sosial}

Analisis wacana kritis model Van Dijk memang terkenal dengan kognisi sosialnya. selain melihat dari segi linguistik Van Dijk juga melihat dari segi kognisi sosialnya yang melihat bagaimana wacana tersebut bisa terbentuk dan apa yang mempengaruhi penulis saat menulis wacana tersebut.

Ada beberapa indikator yang dilihat dalam kognisi sosial ini yaitu pengetahuan dan budaya serta opini dan sikap. Disini peneliti berusaha menganalisis dari teks pada buku seperti apa pemikiran penulis serta opini yang dikemukakan penulis. beberapa indikator tersebut ada yang secara eksplisit dijabarkan oleh penulis dan ada juga yang secara implisit. Beberapa indikator tersebut didapatkan dari hasil kajian peneliti mengenai kognisi sosial tersebut serta dari beberapa penelitian terdahulu sebagai pendukung penelitian tersebut.

\section{KESIMPULAN DAN IMPLIKASI}

\section{KESIMPULAN}

Analisis wacana kritis kognisi sosial penulis menyajikan beberapa pengetahuan serta budaya

atau kepercayaan masyarakat secara eksplisit (tersurat) dan implisit (tersirat) yang memengaruhi terciptanya wacana kritis seperti budaya sekitarnya yang masih terobsebsi dengan hal-hal baik. Dalam teks wacananya penulis juga mengkritisi motivator yang memberikan motivasi untuk menjadi orang baik penulis juga mengemukakan opini serta sikap terhadap kehidupan sosial yang dialaminya dan menganggap bahwa teori-teori motivasi yang biasa diberikan tidak sepenuhnya benar, hal itulah yang memengaruhi proses pembuatan wacana.

\section{IMPLIKASI TEORITIS}

Analisis wacana kritis model Van Dijk bisa dibilang sebagai analisis wacana kognisi sosial karena menurut Van Dijk wacana tidak hanya dapat dilihat dari struktur teks saja melainkan harus dilihat juga dari kognisi sosialnya. Kognisi sosial melihat bagaimana proses suatu wacana bisa terbentuk (Eriyanto, 2002).

Elemen-elemen yang digunakan dalam analisis wacana kritis model Van Dijk ini dapat mengungkap maksud dan tujuan penulis serta alasan penulis dalam pembuatan wacana. Analisis wacana kritis model Van Dijk juga dapat mengungkap bagaimana sosial budaya yang berusaha penulis sampaikan melalui teks.

\section{IMPLIKASI PRAKTIS}

Hasil penelitian ini pada proses pelaksanaannya adalah agar pembaca lebih memahami apa yang sebenarnya penulis ingin sampaikan serta sebagai motivasi kepada pembaca agar lebih menerima diri sendiri dan tidak memerdulikan suatu hal yang tidak penting sebagaimana inti dari buku tersebut. Selain itu, penelitian ini dapat memberi motivasi kepada pembaca agar lebih kritis dalam memaknai suatu teks. Penelitian ini juga bisa dikembangkan dengan metode dan model yang berbeda. 


\section{DAFTAR PUSTAKA}

\section{Buku}

Eriyanto. (2012). Anlisis Framing:

Komunikasi, Ideologi dan Politik

Media. Yogyakarta:

LKIS.

Eriyanto. (2002). Analisis Wacana:

Pengantar Analisis Teks Media.

Yogyakarta: LkiS Group.

Siswasih, dkk. 2007. Bahasa dan Sastra

Indonesia untuk SMK Kelas XII.

Bekasi: PT Galaxi Puspa Mega.

Hamad, Ibnu (2004) Konstruksi Realitas

Politik dalam Media Massa. Jakarta: Granit.

Handayani, Mitri. (2010). Analisis Wacana

Pesan Cinta Dalam Kumpulan Cerita

Pendek Emak Ingin Naik Haji Karya

Asma Nadia. Skripsi Komunikasi

Penyiaran Islam.

\section{Jurnal}

Musyafa'ah, Nurul. (2017). Analisis Wacana Kritis Model Teun A. Van Dijk "Siswa Berprestasi jadi Pembunuh". Jurnal Program Studi PGMI. 4 (2):205

Humaidi, Akhmad. (2017). Struktur Teks, Kognisi Sosial, dan Dimensi Sosial Pidato Susilo Bambang Yudhoyono (Text Structure, Social Cognition, and Sosial Dimention Susilo Bambang Yudhoyono's Speech). Diakses Februari 2020.

https://ppjp.ulm.ac.id/journal/ind ex.php/ibsp/article/view/3744 https://wwwlektur.id 